\title{
Psychological Effects Of Recurrent Miscarriage On Women
}

\author{
Asma Manzoor \\ Shagufta Nasreen \\ Aliyah Ali \\ \& \\ Syed Faisal Hashmi \\ Women's Studies \\ University of Karachi
}

\begin{abstract}
This study tries to explore the psychological, social and emotional experiences of the women who have gone through the recurrent miscarriages. Although miscarriage is seen as common and occurs frequently in otherwise healthy women and in most of the cases the reasons are never known. The phenomenon of miscarriage does not qualify as a disease or even a medical condition. The purpose of this study is to gain a more comprehensive view of the psychological and emotional experiences, the behavioural changes and both supportive and unsupportive factors following miscarriage.

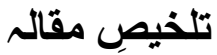

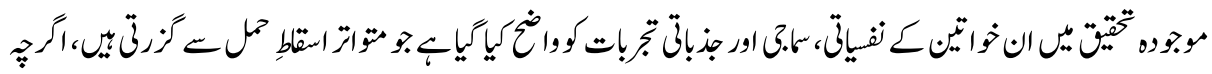

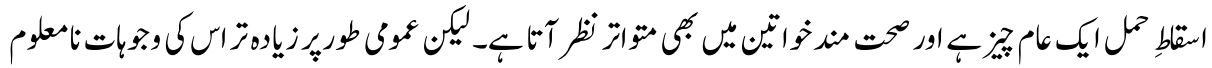

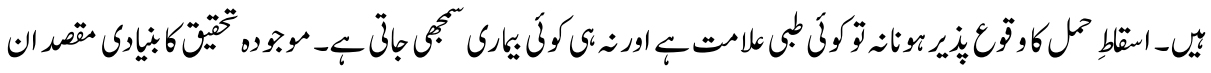

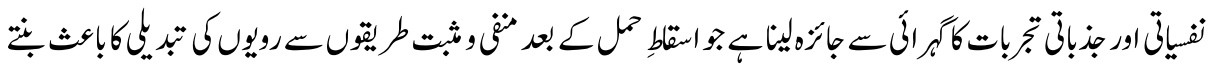

$$
\begin{aligned}
& \text { ثي }
\end{aligned}
$$

Key Words: Miscarriage, Recurrent miscarriage, Anxiety, Depression, Guilt, Self blame Grief

\section{Introduction}

"Health" is defined in the constitution of the World Health Organization as state of complete physical, mental and social well being and not merely the absence of disease or infirmity. The health status of women and the disparities in health between the sexes are often critical indicators of equity in a society. Total health having the highest possible standards of health and well-being is as important and necessary to women as to any other segment of the population. It is a universal human right. During the survey women find herself reluctant to answer the questions in presence of their family members, fearing that what she said might reflect poorly to her family. Furthermore, when it comes 
specifically to health, women have a minor role in decision making. The traditional healers, herbalists and diviners of the region are men. Although women can learn much about traditional diseases concepts and medical practices while nursing the sick. The distinct roles and behaviors of men and women in a given culture, dictated by that culture, norms and values, give rise to gender differences. Gender norms and values, however also give rise to gender inequalities that is, differences between men and women which systematically empower one group to the detriment of the other. Both gender differences and gender inequalities can give rise to inequities between men and women health status and access to health care. Gender norms, values and behaviors are negatively affected health of women. In fact, the gender picture in a given time and place can be one of the major obstacle sometimes the single most important obstacle standing between men and women achievement of well-being. Despite the fact that gender norms and behaviors affect the health but they are associated with the life events of women and men and it can be said primarily with women. These events have psychological impacts on women. Although the research studies mainly focus the biological changes female life events but the normal reactions to these crucial phases in women's lives have been ignored. A wide range of both positive and negative emotions are experienced by the pregnant woman, her spouse, as well as close family members, friends and especially the obstetrician. Her thoughts will range from very practical to very abstract. Child birth will be an extremely intense experience, a combination of exhilaration, pain and accomplishment. Motherhood entails activities which can give an intense blend of joys and difficulties to a woman (Niaz, 2000). Pregnancy has various health issues and it needs careful monitoring in all trimesters. If it is not treated properly it may cause several serious health issues such as abortions, miscarriages, sometimes premature deliveries and later pregnancy issues, these all impact females psychologically. Abortion and miscarriage may both be experienced as profoundly distressing events, even though physically they may cause little upheaval if the pregnancy ends at an early stage. A spontaneous abortion or miscarriage occurring early and without complications may not require hospital admission or emergency treatment. Nevertheless, it is likely to come as a great shock, and may cause revulsion if the concepts are recognizable as a formed fetus, perhaps passed into a bucket or the lavatory pan. The need to dispose of this as waste may become a haunting memory.

A miscarriage may be the first unexpected event in the married life of a young couple who have been anticipating a normal pregnancy and joyous birth. If the pregnancy has been unplanned though not necessarily unwanted, miscarriage may be associated with some relief, but may bring remorse in its wake. Husband often feel guilty and unable to offer support and help, indicating their bewilderment and sense of exclusion from an event that, while involving the woman in an intimately personal and physical way, is quite literally outside the husband's experience. He may seek for rational explanations for this untoward occurrence, express anger that it should have happened, be embarrassed at 
any mention of the event or be irritated at his wife's grieving. A husband may alarm and confused at the change in his partner if she becomes seriously depressed. (Ashurst, 1989).

In developing countries the complications of pregnancy and delivery are the leading causes of death and disability among women of child bearing age. Complications arising during pregnancies and childbirth can be neither predicted nor prevented. In Pakistan 12 percent of pregnancies resulted in miscarriages in the five years before the survey, almost 2 percent resulted in an abortion, and 3 percent resulted in a stillbirth. (National Institute of Population Studies (December 2012-13)

A miscarriage is the loss of a baby before the 20th week of pregnancy mostly happening during the first 12 several weeks. Miscarriages occur in about 15 percent of recognized pregnancies. About 85 percent of women who miscarry go on to have a healthy pregnancy the next time (American Psychiatric Association 1994). The medical name for miscarriage is spontaneous abortion. Suffering a miscarriage is one of the most harmful things that can occur to a woman, and to her associate. Many women conceive easily and are not psychologically or actually ready for the great shock of losing a child. One in four pregnancies ends in miscarriage, usually before the twelfth week of pregnancy. Many women miscarry without having been aware that they were expecting. Many women feel well and will not observe anything unpleasant before a check up verifies that the child has stopped developing and died. In this scenario, the miscarriage is known as 'missed abortion' because the child has passed away, but has not been removed from the womb. In some situations, a fertilized egg will not have developed, or developed poorly. On a check out, this would show as a pregnancy, but there would be no embryo because the fetus will have stopped growing early on. This is known as a 'blighted ovum' (Glenville, Dr. Marilyn).

The concept of reproductive health arose in the 1980s with a growing activity away from inhabitants control and demographic targets towards a more natural approach to women's wellness. It was not until the ICPD in 1994 and the Fourth World Conference on Women (FWCW) in 1995 that the idea obtained worldwide approval and was heralded as a turning point for women's wellness. The ICDP brought to worldwide identification two essential directing concept of RSH: 1) that strengthening women as well as enhancing their position are essential ends in themselves and essential for achieving sustainable development; and 2) reproductive rights are inextricable from basic human rights, rather than something belonging to the realm of family planning (MacDonald, Kelly).

Almost all miscarriages-60 percent or so-come about because of a mis-combination of the chromosomes of the egg and sperm when they fuse at conception, four out of five times when the egg and sperm fuse a proper and balanced embryo outcomes. One out of five times, however, the chromosomes of the egg and sperm do not merge properly 
leading to the embryo having abnormal chromosomes. But there are other causes for miscarriage as well. These range from abnormalities of a woman's reproductive organsuch as a womb that has huge fibroids-to hormonal inadequacy, infection, or harmful environmental influences. The reason for miscarriage is varied, and most often the cause cannot be identified. During the first trimester, the most typical cause of miscarriage is chromosomal abnormality - meaning that something is not correct with the baby's chromosomes. Most chromosomal abnormalities are the cause of a faulty egg or sperm cell, or are due to a problem at the time that the zygote went through the division process (Today's Parent Staff, 2012).

Unfortunately, miscarriage can impact anyone. It can make women disbelieve and cause them to depressive disorders. Women are often left with unanswered questions concerns regarding their physical recovery, their psychological restoration and trying to conceive again. It is very important that women try to keep the lines of communication open with family, friends and health care providers during this time.

Consequently, women are left feeling angry, frustrated, guilty, and out of control after things do not go as planned. Lee discussed ways in which women seek to regain emotions of control, such as by accusing themselves, and analyzing every moment and aspect of their pregnancies looking for a possible cause (Lee, 1996). Given this factor of lost control, Walker and Davidson (2001) examined whether recognized symptoms of a miscarriage would impact women's level of distress. Although researchers hypothesized that women who recognized symptoms of an early pregnancy loss would be less mentally troubled in the three week period following a miscarriage than women who experienced no indicators, they found that the existence of recognized indicators did not impactt levels of emotional problems. In fact, the experience of early pregnancy loss itself, regardless of recognized symptoms of any pregnancy complications, increased posttraumatic stress symptoms and anxiety (Walker, 2001).

In the same way, a research by Nikcevic, et.al (2000) showed that women's distress following a miscarriage is not affected by the provision of information about the cause of the pregnancy loss. In other terms, results revealed that women experienced significant distress levels, especially anxiety, whether or not details about a particular cause was recognized and provided. These findings seem to indicate that the sense of loss experienced by women who experience a single miscarriage or Recurrent Miscarriage $(\mathrm{RM})$ is so great that no level of preparation or provision helps to reduce the devastation. Perhaps this is because, with or without a caution, a miscarriage epitomizes the experience of having no control as it is, essentially, the complete loss of control over someone's body (Nikcevic, 2000). 


\section{Causes of Miscarriages}

The cause for miscarriage is varied, and most often the cause cannot be recognised. During the first trimester, the most common cause of miscarriage is genetic issue significance that something is not appropriate with the baby's chromosomes. Most genetic abnormalities are the cause of a defective egg or sperm cell, or are due to an issue at the time that the zygote went through the division process (Amos, Dr. David).

Most miscarriages occur because the fetus is not developing normally. Problems with the baby's genes or chromosomes are generally caused by chance as the embryo separates and develops - not problems inherited from the mother and father. Some examples of abnormalities include: Blighted ovum which occurs when a fertilized egg produces a placenta and tissue layer but no embryo, it is a common cause of about $50 \%$ of all miscarriages that occur in the first 12 several weeks. Another abnormality is Intrauterine baby death, in this scenario the embryo is present but has passed away before any signs of pregnancy loss have occurred. This situation may also be due to inherited abnormalities within the embryo. A molar pregnancy, also called gestational trophoblastic disease it is less common and occurring in about 1 in 1,000 pregnancies. It is an abnormality of the placenta due to a problem at fertilization. In a molar pregnancy, the early placenta produces into a fast-growing mass of cysts in the uterus. This mass may or may not contain an embryo. If it does contain an embryo, the embryo will not reach maturity (Myao Foundation for Medical Education and Research, 2010).

\section{Islamic View about Miscarriage:}

It was narrated from Mu'aadh ibn Jabal that the Prophet (peace and blessings of Allah be upon him) said:

"By the One in whose hand is my soul, the miscarried fetus will drag his mother by his umbilical cord to Paradise, if she (was patient and) sought reward (for her loss) (Fatwa No. 71161)." Narrated by Ibn Maajah, 1609; classed as da'eef by al-Nawawi in al-Khulaasah (2/1066) and al-Boosayri, but classed as saheeh by al-Albaani in Saheeh Ibn Maajah.

The evidence for that are the words of the Prophet (peace and blessings of Allah be upon him):

"The miscarried fetus should be prayed over (the funeral prayer), and supplication for forgiveness and mercy for his parents should be offered (Fatwa No.71161)." (Narrated by Abu Dawood; classed as saheeh by alAlbaani in Saheeh al-Jaami', 3525)

"O mankind! If you are in doubt about the Resurrection, then verily We have created you (i.e. Adam) from dust, then from a Nutfah (mixed drops 
of male and female sexual discharge i.e. the offspring of Adam), then from a clot (a piece of thick coagulated blood) then from a little lump of flesh some formed and some unformed (as in the case of miscarriage) - that We may make (it) clear to you (i.e. to show you Our Power and Ability to do what We will). And We cause whom We will to remain in the wombs for an appointed term, then We bring you out as infants, then (give you growth) that you may reach your age of full strength. And among you there is he who dies (young), and among you there is he who is brought back to the miserable old age, so that he knows nothing after having known. And you see the earth barren, but when We send down water (rain) on it, it is stirred (to life), and it swells and puts forth every lovely kind (of growth) (The Holy Quran, Al-Hajj, Chapter 22, Verse 5)."

\section{Myth and Reality}

Miscarriage, a far more common and more psychologically harmful event than most people realize, is full of belief and misapprehensions that often lead to profound guilt, deep grief, strong sadness, fear of subsequent pregnancies and sometimes irreparable harm to the marriage relationship. It is nearly difficult to affect a regular, healthy pregnancy through physical exertion or trauma. In a majority of cases specific researches have shown miscarried fetuses are genetically abnormal and incapable to endure. However, couples suffering miscarriages are hardly ever informed this and generally feature their misfortune to a variety of activity that can be guilt provoking and lifedisruption. Numerous surveys have also proven that 15-20\% of known pregnancies end in spontaneous abortion, the medical term for miscarriage (Brady, 1982).

According to Pamela and Kathy the threat that miscarriage will occur in the first three months of pregnancy increases with advancing age of the women, approximately increasing from the twenties to the early thirties, and then increasing again from the early to the late thirties. With more women these days delaying childbearing until their thirties and then wanting a child as soon as they made the decision they are prepared for becoming a mother - miscarriage is likely to become more common and more emotional an experience (Daniel, 1982).

Despite the frequency of miscarriage and the severe psychological stress and trauma it can cause, it remains an almost taboo subject. Even after the event there is often a breakdown in communications between doctor and patient that results couples with bad psychological injuries.

According to Dr. Richard Schwarz, chairperson of obstetric and gynecology at the Downstate Medical Centre in Brooklyn, "Miscarriage is a natural-selection process in 
most cases, not some one's fault", this is particularly true of miscarriage during the first three months of pregnancy which represent the overwhelming majority. Later, however, miscarriage is more likely to result from anatomical abnormalities in the mother, such as cervix that cannot hold up against the stress of the growing womb. According to Dr. Ross E. Rocklin when no other basis can be found for repeated miscarriages, an immunological abnormality is the likely cause. If a woman has had one or more miscarriages, there is a 25 to $40 \%$ chance that she will have another, a probability not much greater that the $20 \%$ she faces before her first pregnancy (Brady, 1982).

A research performed at Queen Marry Hospital, The University of Hong Kong shows that "though miscarriage is common, women are often unprepared for the loss and suffer a range of psychological reactions from grief, to anxiety and depression". The findings of the research highlight the significance of early identification and appropriate management process to help improve the psychological well-being of women who miscarry (Ravi, 2013).

\section{Objectives}

To compare the psychological trauma reactions of women who had recurrent miscarriage.

\section{Methodology}

Existing research is based upon the primarily quantitative and narrowly focused qualitative investigation of the psychological effects of recurrent miscarriage, the researcher along with a research team comprised of one student and two colleagues conducted a study through questionnaire method. A sample of fifty women aged between 20 to 30 years was recruited having at least two miscarriages. Researcher made no specific hypothesis but focused on primarily the relationship between miscarriage and loss/ grief and provides a comprehensive range of psychological and emotional consequences of recurrent miscarriage by examining it qualitatively. Participants provided rich description of the psychological impact and factors of miscarriage which affect their lives.

\section{Results and Discussion}

Table 1

Distribution of Respondents According to the Age when they Get Married

\begin{tabular}{|l|c|c|}
\hline Age & Frequency & Percentage \\
\hline $20-25$ & 30 & $60 \%$ \\
\hline $26-30$ & 20 & $40 \%$ \\
\hline Total & $\mathbf{5 0}$ & $\mathbf{1 0 0 \%}$ \\
\hline
\end{tabular}


Table 2

Distribution of Respondents According to Consensual or non Consensual Marriage

\begin{tabular}{|l|c|c|}
\hline Consensual marriage & Frequency & Percentage \\
\hline Yes & 45 & $90 \%$ \\
\hline No & 5 & $10 \%$ \\
\hline Total & $\mathbf{5 0}$ & $\mathbf{1 0 0 \%}$ \\
\hline
\end{tabular}

Table 3

Distribution of Respondents According to Number of Pregnancies

\begin{tabular}{|l|c|c|}
\hline Number of pregnancies & Frequency & Percentage \\
\hline $1-3$ & 40 & $80 \%$ \\
\hline $4-6$ & 10 & $20 \%$ \\
\hline Total & $\mathbf{5 0}$ & $\mathbf{1 0 0 \%}$ \\
\hline
\end{tabular}

Table 4

Distribution of Respondents According to Number of Children Delivered Alive

\begin{tabular}{|l|c|c|}
\hline $\begin{array}{l}\text { Number of children delivered } \\
\text { alive }\end{array}$ & Frequency & Percentage \\
\hline $1-2$ & 43 & $86 \%$ \\
\hline $3-4$ & 7 & $14 \%$ \\
\hline Total & $\mathbf{5 0}$ & $\mathbf{1 0 0 \%}$ \\
\hline
\end{tabular}

Table 5

Distribution of Respondents According to the Number of Miscarriage(s)

\begin{tabular}{|l|c|c|}
\hline Number of miscarriage(s) & Frequency & Percentage \\
\hline 1 & 5 & $10 \%$ \\
\hline 2 & 37 & $74 \%$ \\
\hline 3 & 8 & $16 \%$ \\
\hline Total & $\mathbf{5 0}$ & $\mathbf{1 0 0} \%$ \\
\hline
\end{tabular}

Table 6

Distribution of Respondents According to the Age at First Miscarriage

\begin{tabular}{|l|c|c|}
\hline Age at first miscarriage & Frequency & Percentage \\
\hline $20-25$ & 28 & $56 \%$ \\
\hline $26-30$ & 22 & $44 \%$ \\
\hline Total & $\mathbf{5 0}$ & $\mathbf{1 0 0 \%}$ \\
\hline
\end{tabular}


Table 7

Distribution of Respondents According to the Family History of Miscarriage

\begin{tabular}{|l|c|c|}
\hline Family history of miscarriage & Frequency & Percentage \\
\hline Common & 8 & $16 \%$ \\
\hline Uncommon & 42 & $84 \%$ \\
\hline Total & $\mathbf{5 0}$ & $\mathbf{1 0 0 \%}$ \\
\hline
\end{tabular}

Table 8

Distribution of Respondents According to the Month/Week Facing Miscarriage

\begin{tabular}{|l|c|c|}
\hline Month/week facing miscarriage & Frequency & Percentage \\
\hline 6-12 week & 15 & $30 \%$ \\
\hline 13-18 week & 20 & $40 \%$ \\
\hline 19-24 week & 15 & $30 \%$ \\
\hline Total & $\mathbf{5 0}$ & $\mathbf{1 0 0} \%$ \\
\hline
\end{tabular}

Table 9

Distribution of Respondents According to Nutrition/Diet during Pregnancy

\begin{tabular}{|l|c|c|}
\hline Nutrition/diet during pregnancy & Frequency & Percentage \\
\hline Good nutrition & 3 & $6 \%$ \\
\hline Normal nutrition & 32 & $64 \%$ \\
\hline Malnutrition & 15 & $30 \%$ \\
\hline Total & $\mathbf{5 0}$ & $\mathbf{1 0 0 \%}$ \\
\hline
\end{tabular}

Table 10

Distribution of Respondents According to the Cause of Miscarriage

\begin{tabular}{|l|c|c|}
\hline Cause of miscarriage & Frequency & Percentage \\
\hline Known & 28 & $56 \%$ \\
\hline Unknown & 22 & $44 \%$ \\
\hline Total & $\mathbf{5 0}$ & $\mathbf{1 0 0 \%}$ \\
\hline
\end{tabular}

Table 11

Distribution of Respondents According to the Miscarriage due to the Negligence

\begin{tabular}{|l|c|c|}
\hline $\begin{array}{l}\text { Miscarriage due to the } \\
\text { Negligence }\end{array}$ & Frequency & Percentage \\
\hline Spouse & 5 & $10 \%$ \\
\hline Family member & 18 & $36 \%$ \\
\hline Self & 5 & $10 \%$ \\
\hline No negligence & 22 & $44 \%$ \\
\hline Total & $\mathbf{5 0}$ & $\mathbf{1 0 0 \%}$ \\
\hline
\end{tabular}


Table 12

Distribution of Respondents According to their Relationship with their Husband

\begin{tabular}{|l|c|c|}
\hline Relation with Husband & Frequency & Percentage \\
\hline Good & 33 & $66 \%$ \\
\hline Bad & 17 & $34 \%$ \\
\hline Total & $\mathbf{5 0}$ & $\mathbf{1 0 0 \%}$ \\
\hline
\end{tabular}

Table 13

Distribution of Respondents According to their Relationship with In-Laws

\begin{tabular}{|l|c|c|}
\hline Relationship with in-laws & Frequency & Percentage \\
\hline Good & 20 & $40 \%$ \\
\hline Bad & 30 & $60 \%$ \\
\hline Total & $\mathbf{5 0}$ & $\mathbf{1 0 0 \%}$ \\
\hline
\end{tabular}

Table 14

Distribution of Respondents According to the Husband and his Family Reaction

\begin{tabular}{|l|c|c|}
\hline $\begin{array}{l}\text { Husband and his family } \\
\text { reaction }\end{array}$ & Frequency & Percentage \\
\hline Positive & 20 & $40 \%$ \\
\hline Negative & 30 & $60 \%$ \\
\hline Total & $\mathbf{5 0}$ & $\mathbf{1 0 0 \%}$ \\
\hline
\end{tabular}

Table 15

Distribution of Respondents According to the Psychological Effects of Miscarriage

\begin{tabular}{|l|c|c|}
\hline Psychological Effects & Frequency & Percentage \\
\hline Self blame & 8 & $16 \%$ \\
\hline Guilt & 3 & $6 \%$ \\
\hline Feeling of loss & 3 & $6 \%$ \\
\hline Acute trauma & 10 & $20 \%$ \\
\hline Sadness and grief & 6 & $12 \%$ \\
\hline Depression & 14 & $28 \%$ \\
\hline Anxiety & 6 & $12 \%$ \\
\hline Total & $\mathbf{5 0}$ & $\mathbf{1 0 0} \%$ \\
\hline
\end{tabular}


Table 16

Distribution of Respondents According to the Duration of Depression

\begin{tabular}{|l|c|c|}
\hline Duration of depression & Frequency & Percentage \\
\hline $1-2$ weeks & 17 & $34 \%$ \\
\hline $1-2$ months & 13 & $26 \%$ \\
\hline $3-4$ months & 5 & $10 \%$ \\
\hline $5-8$ months & 5 & $10 \%$ \\
\hline $1-2$ years & 5 & $10 \%$ \\
\hline $3-4$ years & 5 & $10 \%$ \\
\hline Total & $\mathbf{5 0}$ & $\mathbf{1 0 0 \%}$ \\
\hline
\end{tabular}

Many of the women expressed their fear that the possibly miscarrying again if they become pregnant. They don't want to go through this terrible physical and emotional pain again. It was a very strange behavior but this fear is because of their in-laws and husbands' behavior that their husband would leave them or their in-laws forced their husbands to leave them if did not successfully conceive again. This also develops a feeling of guilt, shame, disappointment and self-blaming in the respondents. The only thing that take them out from their emotional and psychological set back to their normal life is the form of emotional support and care provided by their husband, family and friends.

\section{Discussion}

Analyses revealed that the emergence of the research which documented the experiences of the participants reflect the findings from previous researches related to the relationship between miscarriage, anxiety, depression and acute trauma as discussed in this study. Sadness and grief for the lost child and the hopes regarding ever having a child was found throughout the participants responses. All of them cried during interview and directly expressing their sadness and feeling of grief. Building upon previous researches these qualitative descriptions highlighted the hopelessness that specifically accompanies recurrent miscarriage with subsequent losses and the realization of possibly never having their own children. As one of the respondent said that she never thought that she could ever go through anything as painful as this happened to them not one or two losses but three. She realized that she had gone through the most painful thing of her life where she thinks that she may never recover. She was so depressed and asking Allah all the time why this happened to me.

Anxiety was also very evident in almost all the respondents, research findings shows that anxiety is a form of sense of having lost control when a woman miscarries or repeatedly miscarries. One of the respondent said that she not only lost her control over her own body but psychologically she feels that she has lost her control over her ability to give 
protection to her unborn child. After her first miscarriage she noticed herself a behavioural change in her attitude. She had a feeling that if she got pregnant again what would happen to her, she was so worried about everything. Basically it was a trauma in which she had night mares and flashbacks which always haunts them. It is very evident that the shock, stress and traumatic reactions related to the emotional loss as well as the physical process of miscarriage. She also shared that it was a most horrible pain and a nightmare when she actually passed the fetus.

In societies like Pakistan where women are supposed to be equipped with child bearing capacity and the responsibility and immense pressure of reproduction creates gender inequality and this discrimination negatively affect women's health directly or indirectly throughout their life span. There are some socio-cultural constraints, social injustice and poverty which normally keep women ignorant of their rights. Unequal relationship between spouses also hampers women to have control on their bodies and decision making regarding the size of the family. The findings also revealed that women have limited knowledge of their reproductive health problems and due to that they suffered miscarriages. It can make women disbelieve and lead them to depression. Women are often left with unanswered questions regarding their physical recovery, their emotional recovery and trying to conceive again. It is very important that women try to keep the lines of communication open with family, friends and health care providers during this time.

Unfortunately, reliable data based on scientific research on recurrent miscarriage is somehow inadequate and does not reflect the socio-cultural factors related to the issue. Pakistan Family Planning and Reproductive Health Survey was conducted in 2001, according to that survey $23 \%$ of the married women had experienced at least one or more miscarriages in their life (Pakistan Family Planning and Reproductive Health Survey 2001). This study also reemphasized that investment in female education sector is essentially needed to ensure their reproductive health. The study also revealed the fact that poverty and lack of knowledge about reproductive health become a major cause for recurrent miscarriages. Gender inequality and socio-economic status also confined women to their homes and deprived them of opportunities for education, access to information and proper health care services.

\section{References}

American Psychiatric Association (1994). Diagnostic and Statistical Manual of Mental Disorders. 4th ed. Washington D.C.: American Psychiatric Association., p, 427.

Amos, Dr. David, Miscarriage and Signs of a Miscarriage, http://www.babymed.com/ miscarriage, Retrieved on $25^{\text {th }}$ July 2013. 
Ashurst, Pamela \& Hall, Zahida (1989). Understanding Women In Distress, Routledge, London, p115-116).

Brady, Jane E. (1982). Guide to Personal Health, Times Books, New York, pp, 218-221.

Daniel, Pamela, Weingarten, Kathy (1982). Sooner or Later: The timing of parenthood in adult lives, W.W. Norton, New York.

Fatwa No. 71161, Ruling on Miscarried Foetus, http://islamqa.info/en/71161 and see also http://islam.worldofislam.info/index.php?option $=$ com content\&view $=$ article\&catid=127\&id=730:misscarriage-and-foetus, Retrieved on $20^{\text {th }}$ July 2013.

Glenville, Dr. Marilyn http://www.marilynglenville.com/womens-health-issues/ miscarriage/, Retrieved on $20^{\text {th }}$ July 2013.

Lee C, Slade P. (1996). Miscarriage as a Traumatic event: a Review of Literature and New Implications for intervention. J Psychosom Res: 40, p, 232-245.

MacDonald, Kelly, Reproductive Health, http://www.forcedmigration.org/researchresources/expert-guides/reproductive-health/ fmo031.pdf, Retrieved on $16^{\text {th }} \mathrm{Sept}$ 2013.

Mayo Foundation for Medical Education and Research (updated 2010) Miscarriage, http://edition.cnn.com/HEALTH/library/pregnancy-loss-miscarriage/ DS01105. html, Retrieved on 25th July 2013.

Nikcevic, A.V., Kuczmierczyk, A.R., Tunkel, S.A. \& Nicolaides, K.H. (2000)

Distress after Miscarriage: Relation to the Knowledge of the Cause of Pregnancy Loss and Coping Style. Journal of Reproductive and Infant Psychology, 18(4), pp, 339-343. ISSN (print) 0264-6838

Pakistan Family Planning and Reproductive Health Survey (2001).

Ravi, Thilaka (2013). Women Using Assisted Reproductive Suffer Greater Psychological Trauma After Miscarriage, Mental Health News., http://www.medindia.net/news/women-using-assisted-reproduction-suffergreater-psychological-trauma-after-miscarriage-118242-1.htm, Retrieved on 8th Sept., 2013.

The Holy Quran (Al-Hajj, Chapter 22, Verse 5). 
Today's Parent Staff (2012). Common Miscarriage Questions, http://www. todaysparent. com/pregnancy/common-miscarriage-questions/ Retrieved on $20^{\text {th }}$ Oct. 2013.

Walker, T. \& Davidson, K. (2001). A Preliminary Investigation of Psychological Distress Following Surgical Management of Early Pregnancy Loss Detected at Initial Ultrasound Scanning: A Trauma Perspective. Journal of Affective Disorders, 41, p, 173-180.

Dr. Asma Manzoor is Teaching Associate in the Centre of Excellence for Women's Studies, University of Karachi.

Dr. Shagufta Nasreen is Teaching Associate in the Centre of Excellence for Women's Studies, University of Karachi.

Dr. Aliyah Ali is Teaching Assistant in the Centre of Excellence for Women's Studies, University of Karachi.

Syed Faisal Hashmi is Research Officer in the Centre of Excellence for Women's Studies, University of Karachi. 